\title{
Tinjauan Sosiologis Eksekusi Benda Jaminan Fidusia Dan Hambatan - Hambatannya (Studi Kasus Di PT. Fifgroup Cabang Selong Lombok)
}

\section{Lalu Muhammad Faisal}

\begin{abstract}
Abstrak. Tujuan penelitian untuk mengetahui bagaimna prosudural eksekusi benda jaminan fidusia dan hambatan-hambatannya serta prosudural pelaksanaanya pada PT. FIFGROUP Cabang Selong Lombok Timur. Metode penelitian yang digunakan penulis mengunakan Empiris. Berdsarkan hasil penelitian penulis pada PT. FIFGROUP Cabang Selong Lombok Timur mengenai Proses prosudural eksekusi benda jaminan fidusia sudah sesuai dengan Undang-Undang No. 42 Tahun 1999 Tentang Jaminan Fidusia dengan melalui beberapa tahapan yaitu teguran secara langsung, dan teguran tertulis. Mengenai hambatan prosudural yang dialami oleh PT. FIFGROUP Cabang Selong Lombok Timur dalam hal hambatan prosudural legalitas karna kurangnya pemahaman debitur akan pentingnya sadar hukum dan dalam melakukan eksekusi debitur tidak memiliki i'tikad baik untuk menyelesaikan prestasinya atas wanprestasi yang dilakukan kepada Kreditur.
\end{abstract}

Kata Kunci : Prosudural-Hambatan-Eksekusi.

\section{PENDAHULUAN}

A. Latar Belakang Masalah

Persoalan ekonomi dapat dikatakan sama tuanya dengan sejarah manusia itu sendiri. Persoalan-persoalan ekonomi yang terdapat pada tingkatan individu, masyarakat, negara (nasional), dan internasional tidak bisa dipecahkan hanya dengan ilmu-ilmu ekonomi namun harus bekerja sama dengan ilmu-ilmu sosial lainnya seperti pendekatan sosiologi, psikologi, antropologi dan politik. Pendekatan sosiologis yaitu kerangka acuan variabelvariabel, dan model-model yang digunakan oleh para sosiolog dalam memahami dan menjelaskan fenomena-fenomena hukum. Sosiologi merupakan bagian dari ilmu filsafat yang mempelajari tentang masyarakat termasuk hubungan antara manusia satu dengan manusia lainnya, baik secara individu mapun kelompok. Menurut William Kornblum "sosiologi adalah upaya ilmiah untuk mempelajari masyarakat dan prilaku sosial anggotanya dan menjadikan masyarakat yang bersangkutan dalam berbagai kelompok dan kondisi".

Melihat permasalahan sosialogis hukum saat ini, dengan mengacu pada perkembangan ekonomi saat, banyak hal yang dapat diamati secara sosiologis hukum dengan melakukan observasi untuk menemukan faktanya.Menurut Satjipto Rahardjo "Sosiologi Hukum adalah cabang ilmu yang mempelajari fenomena hukum dengan mencoba keluar dari batas-batas peraturan hukumdan mengamati hukum sebagaimana dijalankan oleh orangorang dalam masyarakat, dalam pemenuhan pengembangan perekonomian masyarakat, dengan melihat meningkatnya permintaan akan kebutuhan pendanaan oleh masyarakat.

Didalam pasal 1 ayat (11) UndangUndang Nomor. 10 tahun 1998 tentang perubahan atas Undang-Undang Nomor 7 Tahun 1992 tentang Perbankan disebutkan bahwa :

"Kredit adalah penyediaan uang atau tagihan uang yang dapat dipersamakan denganitu,berdasarkan persetujuan atau kesepakatan pinjam meminjam antara bank dengan pihak lain yang mewajibkan pihak peminjam untuk melunasi utangnya setelah jangka waktu tertentu dengan pemberian bunga".

\section{TINJAUAN PUSTAKA}

\section{A. Tinjauan Umum Tentang Perjanjian Jaminan Fidusia}

\section{Pengertian Fidusia dan Jaminan Fidusia.}

Fidusia istilah yang sudah lama dikenal dalam bahasa indonesia. Undang-Undang Nomor. 42 Tahun 1999 tentang Jaminan Fidusia sudah mengunakan istilah " Fidusia". Dengan demikian , istilah " Fidusia " sudah merupakan istilah resmi dalam dunia hukum kita. Akan tetapi, kadang-kadang dalam 
bahasa Indonisia disebut juga dengan istilah “ penyerahan hak milik secara kepercayaan ".Dalam terminologi Belandanya sering disebut dengan istilah lengkapnya yaituFiduciare Eigendom Overdracht, (yang akan ada), yang pada prinsipnya memberikan sedangkan dalam bahasa Inggrisnya secara lengkap sering disebutFiduciary Transfer Of Ownership.

Pengertian jaminan fidusia menurut asal katanya "Fides" yang berarti kepercayaan. Sesuai dengan arti kata ini, maka hubungan hukum antara debitur (Pemberi Fidusia) dan kreditur (Penerima Fidusia) merupakan hubungan hukum yang berdasarkan kepercayaan.Pemberi fidusia percaya bahwa penerima fidusia mau mengembalikan hak milik barang yang telah diserahkan, setelah dilunasi utangnya. Sebaliknya penerima fidusia percaya bahwa pemberi fidusia tidak akan menyalahgunakan barang jaminan yang berada dalam kekuasaannya.

Dari uraian tentang tentang pengertian di atas, dapat dijelskan fidusia merupakan hubungan hukum perdata antara pihak-pihak yang mengikatkan dirinya dalam suatu perjanjian. Hukum perdata adalah segala peraturan atau hukum yang mengatur hak dan kewajiban dalam hubungan antara perseorangan yang mengutamakan kepentingan pribadi.

Dalam hukum perdata sistematika hukum perdata diatur dalam Kitab UndangUndang Hukum Perdata (KUHper) terdiri atas 4 (empat) buku, yaitu sebagai berikut:

a. Buku I Tentang Orang (Van Personen), memuat hukum perseorangan dan hukum kekeluargaan.

b. Buku II Tentang Benda (Van Zaken), memuat hukum benda dan hukum waris.

c. Buku III Tentang Perikatan (Van Verbintennissen), memuat hukum harta kekayaan yang mengenali hak-hak dan kewajiban-kewajiban yang berlaku terhadap orang-orang atau pihak tertentu.

d. Buku IV Tentang Pembuktian Kadaluarsa atau Lewat Waktu (Van Bewijs En Verjaring), yang memuat ketentuan alatalat bukti dan akibat-akibat lewat waktu terhadap hubungan-hubungan hukum.
Menurut pasal 1233BW ada dua macam sumber hukum perikatan, yakni perjanjian (Pasal 1313 s.d 1351BW), dan undang-undang (Pasal 1352 s.d 1380 BW):

1) Hukum perikatan yang bersumber pada perjanjian

\section{Berakhirnya Perjanjian Fidusia}

Secara hukum, jaminan fidusia diatur dalam Undang-Undang Nomor.42 Tahun 1999 Tentang Jaminan Fidusia. Menurut UndangUndang tersebut, jaminan fidusia adalah hak jaminan atas benda bergerak yang tetap berada dalam penguasaan pemberi fidusia (Debitur), sebagai agunan pelunasan hutang tertentu, yang memberikan kedudukan yang diutamakan kepada penerima fidusia (Kreditur) terhadap kreditur lainnya.

\section{Asas Hukum Jaminan Fidusia}

Asas-asas hukum jaminan fidusia yang terdapat dalam Undang-Undang Jaminan Fidusia sebagai berikut:

a. Asas bahwa kreditur penerima fidusia berkedudukan sebagai kreditur yang diutamakan dari kreditur lainnya. Asas ini dapat ditemukan dalam pasal 1 angka 2 Undang-Undang No.42 Tahun 1999 Tentang Jaminan Fidusia. Lebih lanjut Undang-Undang jaminan fidusia tidak memberikan pengertian tentang apa yang dimaksud dengan kreditur yang diutamakan dari kreditur-kreditur lainnya. Namun, dibagian lain yakni Pasal 27 Undang-Undang Jaminan Fidusia No.42 Tahun 1999 dijelaskan pengertian tentang hak yang didahulukan terhadap krediturkreditur lainnya (Preference).Asas ini dianut juga dalam jaminan hipotik.Kedudukan yang diutamakan merupakan hak istimewa yang diberikan Undang-Undang kepada pemegang hipotik.Penejelasan umum angka 4 Undang-Undang Hukum Tangungan Pasal 1150 KUHPerdata.Apabila diperhatikan hak yang didahulukan dari pemegang hak tanggungan

b. Asas bahwa jaminan fidusia tetap mengikuti benda yang menjadi objek jaminan fidusia dalam tangan siapapun benda tersebut berada.Dalam ilmu hukum, asas ini disebut dengan (Droit De Suite atau Zaaksgevolg ). Pengertian droit de 
suite dijelaskan sebagai the right of $a$ creditor to pursue debtors propertyinto the hands of third persons for the enforcement of his claim.Pengakuan asas ini dalam Undang-Undang Jaminan Fidusia menunjukkan bahwa jaminanfidusiamerupakan hak kebendaan (Zakelijk Recht) dan bukan hak perorangan (Persoon Lijk Recht). Dengan demikian, hak jaminan fidusia dapat dipertahankan terhadap siapapun juga dan berhak untuk menuntut siapa saja yang menggangguhak tersebut.

c. Asas bahwa jaminan fidusia merupakan perjanjian ikutan yang lazim disebut asas assesoritas. Asas ini mengandung arti bahwa keberadaan jaminan fidusia ditentukan oleh perjanjian lainnya, yakni perjanjian utama atau perjanjian principal. Perjanjian utama bagi jaminan fidusia adalah perjanjian utang piutang yang melahirkan hutang yang dijamin dengan jaminan fidusia. Dalam Undang-Undang Jaminan Fidusia, asas tersebut secara tegas dinyatakan bahwa jaminan fidusia merupakan perjanjian ikutan dari suatu perjanjian pokok. Sesuai dengan sifat assesoir ini, berarti hapusnya jaminan fidusia juga ditentukan oleh hapusnya hutang atau karena pelepasan hak atas jaminan fidusia oleh kreditur penerima jaminan fidusia.Dengan demikian, perjanjian jaminan fidusia merupakan bagian yang tidak terpisahkan dari perjanjian hutang piutang.

d. Asas jaminan fidusia dapat diletakkan atas hutang yang baru akan ada (Kontijen). Dalam Undang-Undang Jaminan Fidusia ditentukan bahwa objek jaminan fidusia dapat dibedakan kepada hutang yang telah ada dan akan ada.

e. Asas bahwa jaminan fidusia dapat dibebankan terhadap benda yang akanada. Salah satu prinsip yang terkandung dalam pasal ini adalah benda yang ada saat dibuat perjanjian jaminan belum ada tapi dikemudian hari benda tersebut ada, benda yang akan dikemudian hari itu harus dimiliki debitur.

f. Asas bahwa jaminan fidusia dapat dibebankan terhadap bangunan atau rumah yang terdapat diatas tanah milik orang lain. Dalam ilmu hukum asas ini disebut degan asas pemisahan horizontal.Dalam pemberian pembiayaan bank, penegasan asas ini dapat menampung pihak pencari pembiayaan khususnya pelaku usaha yang tidak memiliki tanah tetapi mempunyai hak atas bangunan/rumah.Biasanya hubungan hukum antara pemilik tanah dan pemilik bangunan adalah perjanjian sewa.

g. Asas bahwa jaminan fidusia berisikan uraian secara detail terhadapsubjek dan objek jaminan fidusia. Subjek jaminan fidusia yang dimaksudkan adalah identititas para pihak yakni pemberi dan penerima jaminan fidusia,sedangkan objek jaminan yang dimaksudkan adalah data perjanjian pokok yang dijaminan fidusia, uraian mengenai benda jaminan fidusia, nilai penjaminan dan nilai benda yang menjadi objek jaminan. Dalam ilmu hukum disebut asas spesialitas atau pertelaan.

h. Asas bahwa pemberi jaminan fidusia harus orang yang memiliki kewenangan hukum atas objek jaminan fidusia. Kewenangan hukum tersebut harus sudah ada pada saat jaminan fidusia didaftarkan ke Kantor Fidusia. Asas ini sekaligus menegaskan bahwa pemberi jaminan fidusia bukanlah orang yang wewenang berbuat. Dalam Undang-Undang Jaminan Fidusia, asas ini belum dicantumkan dalam Pasal 8 Undang-Undang Hak Tangungan.

i. Asas bahwa jaminan fidusia harus didaftarkan ke KantorAsas Pendaftaran Fidusia. Dalam ilmu hukum disebut asas publikasi.Dengan dilakukannya pendaftaran akta jaminan fidusia, berarti perjanjian fidusia lahir dan momentum tersebut menunjukkan perjanjian jaminan fidusia adalah perjanjian kebendaan.Asas publikasi juga melahirkan adanya kepastian hukum dari jaminan fidusia.

j. Asas bahwa benda yang dijadikan objek jaminan fidusia tidak dapat dimiliki oleh kreditur penerima jaminan fidusia sekalipun hal itu diperjanjikan.Dalam ilmu hukum disebut atas pendakuan.

k. Asas bahwa jaminan fidusia memberikan hak prioritas kepada kreditur penerima 
fidusia yang terlebih dahulu mendaftarkan ke Kantor Fidusia dari pada kreditur yang mendaftarkan kemudian

1. Asas bahwa pemberi jaminan fidusia yang tetap menguasai benda jaminan harus mempunyai itikad baik (To Goeder Trouw, In Good Fait). Asas iktikad baik di sini memiliki arti subjektif sebagai kejujuran bukan arti objektif sebagai kepatutan seperti dalam hukum perjanjian. Dengan asas inidiharapkan bahwa pemberi jaminan fidusia wajib memelihara benda jaminan, tidak mengalihkan, menyewakan dan menggadaikannya kepada pihak lain.

m. Asas bahwa jaminan fidusia sudah dieksekusi. Kemudahan pelaksanaan eksekusi dilakukan dengan mencantumkan irah-irah "Demi Keadilan Berdasarkan Ketuhan Yang Maha Esa" pada sertifikat jaminan fidusia. Dengan titel eksekutorial ini menimbulkan konsekuensi yuridis bahwa jaminan fidusiamempunyaki kekuatan yang sama dengan putusan pengadilan yang telah memperoleh kekuatan hukum tetap.Dalam hal penjualan benda jaminan fidusia, selain melalui titel eksekutorial, dapat juga dilakukan dengan cara melelang secara umum dibawah tangan.

\section{B. Tinjauan Umum Tentang Fidusia}

1. Obyek dan Subyek Jaminan Fidusia

pasal 3 Undang-Undang Jaminan

Fidusia yang menyatakan bahwa UndangUndang Jaminan Fidusia ini tidak berlaku terhadap :

a. Jaminan fidusia yang berkaitan dengan tanah dan bangunan, sepanjang peraturan Perundang-Undangan yang berlaku menentukan jaminan atas benda-benda tersebut wajib terdaftar. Namun demikian, bangunan di atas milik orang lain yang tidak dapat dibebani jaminan fidusia berdasrkan Undang-Undang Nomor. 4 tahun 1996 Tentanng Hak Tangungan dapat di jadikan objek jaminan fidusia.

b. Hipotik atas kapal yang terdaftar dengan isi kotor berukuran 20 (dua puluh) $\mathrm{m} 3$ atau lebih.

c. Hipotik atas pesawat terbang.

d. Gadai.
Antara objek jaminan fidusia dan subjek jaminan fidusia mempunyai kaitan yang erat, oleh karna benda-benda yang menjadi objek jaminan Fidusia menurut Munir Fuady yaitu, benda tersebut harus dapat dimiliki dan dialihkan secara hukum.Dapat atas benda berwujud yaitu:

1) Dapat juga atas benda tidak berwujud,termaksud piutang.

2) Benda bergerak.

3) Benda yang tidak bergerak yang tidak dapat diikat dengan jaminan fidusia.

4) Benda tidak bergerak yang tidak dapat diikat dengan hipotik

5) Baik atas benda yang sudah ada,maupun terhadap benda yang akan diperoleh kemudian, tidak diperlukan suatu akta pembebanan fidusia itu sendiri.

6) Dapat juga atas satuan jenis benda.

7) Termaksud hasil dari benda yang telah menjadi objek fidusia

8) Termaksud juga hasil klaim asuransi dari benda yang menjadi objek jaminan fidusia

9) Benda persedian (inventory, stock,perdagangan) dapat juga menjadi objek jaminan fidusia.

\section{Pembebanan Jaminan Fidusia}

Sebagaimana perjanjian jaminan hutang lainnya, seperti perjanjian gadai, hipotik, atau jaminan fidusia,maka perjanjian fidusia juga merupakan perjanjian assesoir (perjanjian ikatan).Maksudnya adalah perjanjian assesoir ini tidak mungkin berdiri sendiri, tetapi mengikuti atu membuntuti perjanjian lainnya yang merupakan perjanjian pokok adalah perjanjian hutang.

Ada beberapa tahapan formal yang melekat dalam jaminan fidusia, diantaranya adalah:

a. Tahapan pembebanan dengan pengikatan dalam suatu akta notaris.

b. Tahapan pendaftaran atas benda yang telah dibebani tersebut oleh penerima fidusia, kuasa atau wakilnya kepada kantor pendaftaran fidusia,dengan melampirkan pernyataan pendaftaran.

c. Tahapanpan administrasi yaitu pencatatan jaminan fidusia dalam buku daftar fidusia pada tanggal yang sama dengan tanggal penerimaan permohonan pendaftaran. 
d. Lahirnya jaminan fidusia yaitu pada tanggal yang sama dengan tanggal dicatatnya jaminan fidusia dalam buku daftar fidusia.

\section{Sifat Jaminan Fidusia}

Ketentuan pasal 1 angka 2 UndangUndang Jaminan fidusia menyatakan bahwa jaminan fidusia adalah bergerak,baik yang berwujud maupun tidak berwujud dan benda tidak bergerak,khususnya bangunan yang tidak dapat dibebani jaminan fidusia sebagaimana dimaksud dalam Undang-Undang Nomor. 4 Tahun 1996 Tentang Hak Tangungan yang tetap berada dalam penguasaan pemberi fidusia,sebagai agunan pelunasan utangtertentu, yang memberikan kedudukan yang diutamakan kepada penerima fidusia terhadap kreditur lainnya. Ini berarti UndangUndang jaminan fidusia secara tegas menyatakan jaminan fidusia adalah agunan atas kebendaan atas jaminan kebendaan (Zakelijkezekerheid, Security Right In Rem) yang memberikan kedudukan yang diutamakan kepada penerima fidusia, yaitu hak yang didahulukan terhadap kreditur lainnya. Hak ini tidak dihapus karna adanya kepailitan dan atau liquidasi pemberi fidusia.

Dalam pasal 4 Undang -Undang jaminan fidusia juga secara tegas menyatakan bahwa jaminan fidusia merupakan perjanjian assesoir dari suatu perjanjian pokok yang menimbulkan kewajiban bagi para pihak untuk memenuhi prestasi yang berupa memberikan sesuatu, berbuat sesuatu yang dapat dinilai dengan uang. Sebagai suatu perjanjian asseoir, perjanjian jaminan fidusia memiliki sifat sebagai berikut:

a) Sifat ketergantungan terhadap perjanjian pokok yang keabsahannya, semata-mata ditentukan oleh sah tidaknya perjanjian pokok.

b) Sebagai perjanjian bersyarat, maka hanya dapat dilaksanakan jika ketentuan yang disyaratkan dalam perjanjian pokok telah atau tidak dipenuhi

\section{Pendaftaran Jaminan fidusia}

Pendaftaran jaminan fidusia dilaksakan oleh penerima hak jaminan fidusia (kreditor) dikementerian Hukum dan Hak Asasi Manusia (Kementerian). Pendaftaran jenis ini harus di laksanakan paling lambat 30hari sejak tanggal sertifikat Jaminan Fidusiaditerbitkan dengan menyerahkan imformasi sebagai berikut:

a. Identitas pihak penerima dan pemberi fidusia

b. Tanggal, nomor akta jaminan fidusia, nama, dan tempat kedudukan notaris yang membuat akta jaminan fidusia.

c. Data perjanjian pokok yang dijamin fidusia

d. Uraian mengenai benda yang menjadi objek jaminan fidusia

e. Nilai penjamin.

f. Nilai benda yang menjadi jaminan fidusia.

Jaminan fidusia harus dibuat oleh dan atau dihadapan pejabat yang berwewenang. Pasal 1870 KUH Perdata menyatakan bahwa akta notaris merupakan akta otentik yang memiliki kekuatan pembuktian sempurna tentang apa yang dimuat didalamnya diantara para pihak beserta para ahli warisnya atau para pengganti haknya. Hutang yang pelunasannya dapat dijamin dengan jaminan fidusia adalah:

1) Hutang yang telah ada.

2) Hutang yang akanada dikemudian hari, tetapi telahadadiperjanjian dan jumlahnya sudah tertentu.

3) Hutang yang dapat ditentukan jumlahnya pada saat eksekusi berdasarkan suatu perjanjian pokok yang menimbulkankewajiban untuk dipenuhi.Misalnya hutang bunga atas perjanjian pokok yang jumlahnya akan ditentukan kemudian.

4) Eksekusi Jaminan fidusia.

Eksekusi jaminan fidusia dilakukan apabila debitur atau pemberi fidusia cidera janji dengan sertifikat jaminan fidusia bagi kreditur selaku penerima fidusia akan mempermudah dalam pelaksanaan eksekusi terhadap benda yang menjadi obyek jaminan fidusia, pelaksanaan eksekutorial dari sertifikat jaminan fidusia sebagaimana dalam pasal 29 ayat (1) Undang-Undang Fidusia dapat dilakukan dengan cara :

a. Pelaksanaan titel eksekutorial oleh penerima fidusia ;

b. Penjualan benda yang menjadi obyek fidusia ataskekuasaan penerima fidusia sendiri melalui pelelangan umum, serta mengambil pelunasan piutangnya dari hasil penjualan ; 
c. Penjualan di bawah tangan dilakukan berdasarkan kesepakatan antara pemberi dan penerima fidusia, jika dengan cara demikian dapat diperoleh harga tertinggi yang menguntungkan para pihak. Sedangkan dalam ruang lingkup pengadilan di Indonesia eksekusi ada (2) bentuk yakni :

1) Eksekusi riil adalah yang hanya mungkin terjadi berdasarkan putusan pengadilan, dan untuk melakukan tindakan nyata atau riil yang telah memperoleh kekuatan hukum tetap,bersifat dijalankan terlebih dahulu berbentuk provisi dan berbentuk akta perdamain disidang pengadilan.

2) Eksekusi pembayaran sejumlah uang yang tidak hanya didasarkan atas bentuk akta yang gunanya untuk melakukan pembayaran sejumlah uang yang oleh Undang-Undang disamakan nilainya dengan putusan yang memperoleh kekuatan hukum yang tetap berupa :

a) Grose akta pengangkutan utang.

b) Grose akta hipotik.

c) Grose akta credit verband.

Dalam rangka pelaksanaan eksekusi jaminan fidusia, pemberi fidusia wajib menyerahkan bendayang menjadi objek jaminan fidusia.Apabila pemberi fidusia tidak menyerahkanya pada waktu eksekusi dilaksanakan, penerima fidusia berhak mengambil benda yang menjadi objek jaminan fidusia dan apabila perlu dapat meminta bantuan pihak yang berwewenang. Setiap janji untuk melaksanakan eksekusi terhadap benda yang menjadi objek jaminan fidusia dengan cara yang bertentangan dengan ketentuan tersebut diatas,batal demi hukum.

ada 3 cara eksekusi benda jaminan fidusia, yaitu :

a. Pelaksanaan titel eksetutorial oleh penerima fidusia

b. Penjualan benda yang menjadi objek jaminan fidusia atas kekuasaan penerima fidusia sendiri melalui pelelangan umum serta mengambil pelunasan piutangnya dari hasil penjualan; dan

c. Penjualan dibawah tangan yang dilakukan berdasarkan kesepakatan pemberi dan penerima fidusia jika dengan cara demikian dapat diperoleh harga yang tertinngi dan menguntungkan para pihak.
Eksekusi jaminan fidusia memiliki caracara dalam melakukan eksekusi jaminanan fidusia diantara lain:

1. Eksekusi langsung dengan titel eksekutorial yang berarti sama kekuatannya dengan putusan pengadilan yang berkekuatan hukum tetap.Eksekusi ini dibenarkan oleh Undang-Undang Nomor.42 Tahun 1999 Tentang Jaminan Fidusia, karena menurut pasal 15 ayat (2) Undang-Undang Nomor.42 tahun 1999 Tentang Jaminan Fidusia, sertifikat Jaminan Fidusia Menggunakan irah-irah "Demi Keadilan Berdasarkan Ketuhanan Yang Maha Esa" Yang berarti kekuatannya sama dengan kekuatan putusan pengadilan yang bersifat tetap. Irah-irah ini memberikan titel eksekutorial dan berarti akta tersebut tinggal dieksekusi tanpa harus melalui suatu putusan pengadilan.Karena itu, yang dimaksud dengan fiat eksekusi. Fiat eksekusi adalah eksekusi atas sebuah akta seperti mengeksekusi suatu putusan pengadilan yang telah berkekuatan pasti, yakni meminta fiat dari ketua pengadilan dengan cara memohon penetapan dari ketua pengadilan untuk melakukan eksekusi. Ketua pengadilan akan memimpin eksekusi sebagaimana dimaksud dalam HIR.

2. Pelelangan Umum parate Eksekusi jaminan fidusi yang dapat dilakukan dengan jalan mengeksekusinya, oleh penerima fidusia lewat lembaga pelelangan umum (kantor lelang), dimana hasil pelelangan tersebut diambil untuk melunasi pembayaran tagihan penerima fidusia. Parate eksekusi lewat pelelangan umum ini dapat dilakukan tanpa melibatkan pengadilan sebagaimana diatur dalam pasal 29 ayat (1) huruf b Undang-Undang Nomor. 42 Tahun 1999 Tentang Jaminan Fidusia. Adapun syaratsyarat tersebut adalah :

a. Dilakukan berdasarkan kesepakatan antara pemberi dan penerima fidusi.

b. Jika dengan cara penjualan dibawah tangan tersebut dicapai harga tertinggi yang menguntungkan para pihak.

c. Diberitahukan secara tertulis oleh pemberi dan, atau penerima fidusia kepada pihak pihak yang berkepentingan. 
d. Diumumkan dalam sedikitnya dua surat kabar yang beredar di daerah tersebut.

e. Pelaksanaan penjualan dilakukan setelah lewat waktu satu bulan sejak diberitahukan secara tertulis.

f. Eksekusi terhadap barang perdagangan dan efek yang dapat diperdagangkan. Eksekusi terhadap barang tersebut dapat dilakukan dengan cara penjualan di pasar atau bursa sesuai dengan ketentuan yang berlaku untuk pasar dan bursa tersebut sesuai dengan maksud pasal 31 UndangUndang Nomor. 42 Tahun 1999 Tentang Jaminan Fidusia.

g. Eksekusi juga dapat dilakukan melalui eksekusi jaminan fidusi lewat gugatan biasa. Meskipun Undang-undangNomor. 42 Tahun 1999 Tentang Jaminan Fidusia tidak menyebutkan eksekusi lewat gugatan kepengadilan, tetapi tentunya pihak kreditor dapat menempuh prosedur eksekusi biasa lewat gugatan kepengadilan. Sebab, keberadaan Undang-Undang Nomor. 42 Tahun 1999 Tentang Jaminan Fidusia dengan modelmodel eksekusi khusus tidak untuk meniadakan ketentuan hukum acara umum. Undang-Undang Nomor. 42 Tahun 1999 Tentang Jaminan Fidusia yang bertujuan meniadakan ketentuan hukum acara umum tentang eksekusi umum lewat gugatan ke pengadilan negeri yang berwewenang.

\section{METODE PENELITIAN}

\section{A. Jenis Penelitian}

Jenis penelitian ini adalah empiris. Empiris adalah suatu penjelasan rasional yang berkesesuian dengan obyek yang dijelaskannya, dan harus dinyatakan benar didukung oleh fakta empiris untuk dapat dinyatakan benar. Metode peneltian hukum ini dilakukan untuk mendapatkan data dengan melakukan metode berfikir induktif (melihat titik masalah dari dalam keluar atau dari khusus ke umum) atau melihat kebenaran responden serta fakta yang digunakan untuk melakukan pengujian kebenaran secara koresponden dengan fakta yang mutakhir.

\section{B. Lokasi Penelitian Penelitian.}

Ini akan dilaksanakan di Kabupaten Lombok Timur, khusus nya pada PT.
FIFGROUP Cabang Selong Lombok Timur, Lokasi tersebut dijadikannya obyek penelitian karena relevan dengan judul skripsi penulis.

\section{Jenis dan sumber data}

\section{Data Primer}

Data primer adalah: Data sumber hukum yang mempunyai kekuatan hukum yang mengikat. Seperti Perundang-Undangan, Peraturan Pemerintah, KUHPerdata dan lain-lain.

2. Data Sekunder

Sumber data sekunder ialah bahan hukum utama yang terdiri dari sejumlah keterangan atau fakta yang diperoleh di lokasi penelitian, dan peraturan-peraturan yang ada kaitannya dengan masalah yang diteliti, yang memberikan penjelasan terhadap hukum primer, yang berupa dokumendokumen resmi yang dikeluarkan oleh PT. FIFGROUPCabang Selong Lombok Timur yang ada relavansinya dengan masalah yang diteliti.

3. Bahan hukum tersier

Adalah bahan-bahan hukum penunjang yang memberikan petunjuk atau penjelasan terhadap bahan hukum primer dan sekunder, seperti kamus hukum, kamus bahasa indonesia dan ensiklopedia.

\section{Tekhik Pengumpulan Data}

Teknik Pengumpulan data yang digunakan dalam peneltian ini adalah sebagai berikut :

a. Observasi

Yaitu mengethui keadaan tempat penelitian guna penjajagan dan pengambilan data sekunder mengenai halhal yang berkaitan dengan ciri-ciri demografi dan gambaran umum dari PT. FIFGROUP Cabang Selonglombok Timur.

b. Interviuw ( wawancara )

Yaitu teknik pengumpulan data dengan cara mengajukan pertanyaan yang disusun dalam suatu daftar pertanyaan yang telah dipersiapkan terlebih dahulu atau tertulis kepada responden yaitu pihak-pihak yang terkait dalam pelaksanaan eksekusi benda jaminan fidusia pada PT. FIFGROUPCabang Selong Lombok Timur.

c. Dokumentasi.

Sebagai buktidalam pengumpulan data sekunder. 


\section{E. Metode Pendekatan}

Penulis menggunakan metode pendekatan empiris yakni membahas implementasi ketentuan hukun normatif (UndangUndang)dalam perspektif sosial dan yuridis yang bermaksud menjelaskan legalitas aturanaturan asas hukum, aspek-aspek hukum perihal eksekusi jaminan fidusia, dan dalam perspektif empiris yang dimaksudkan untuk mengetahui pelaksanaan prosudural eksekusi benda jaminan fidusi dan hambatan-hambatannya pada PT. FIFGROUP Cabang Selong Lombok Timur.

\section{F. Teknik Analisis Data}

Yang digukan dalam penelitian skripsi ini adalah deskriptif kualitatif, yang bertujuan mengungkap dan mengambil kebenaran dari studi kepustakaan yaitu peraturan-peraturan tentang eksekusi benda jaminan fidusia,kemudian dengan praktek dilapangan untuk menggambarkan dan memaparkan data yang diperoleh dari hasil penelitian secara jelas mengenai prosudural pelaksanaan eksekusi benda jaminan fidusia sebagai jaminan kredit pada PT. FIFGROUP Cabang Selong Lombok Timur, dan dari hasil analisis tersebut disimpulkan secara deduktif dan digunakan untuk menjawab permasalahan yang ada.

\section{HASIL PENELITIAN DAN PEMBAHASAN}

A. Prosudural Eksekusi Benda Objek

Objek jaminan fidusia merupakan jaminan atas benda bergerak baik yang berwujud atau tidak berwujud yang tidak dapat dibebani hak tangungan sebagaimana dimaksud dalam Undang-Undang Nomor. 4 Tahun 1996 Tentang Hak Tangungan yang tetap berada dalam penguasaan pemberi fidusia, sebagai agunan bagi pelunasan utang tertentu, yang memberikan kedudukan yang diutamakan kepada penerima fidusia terhadap kreditor lainnya.

Dari definisi yang dijelaskan diatas, penulis akan menjelaskan tentang prosudural eksekusi benda objek jaminan fidusia yang terbagi menjadi 2 (dua):

1. Prosudural LegalitasEksekusi Benda Objek jaminan fidusia

Perjanjian fidusia disyaratkan dalam Undang-Undang jaminan Fidusia untuk dituangkan dalam akta otentik yang dibuat oleh pejabat yang berwewenang.Akta otentik merupakan salah satu alat bukti, mempunyai kekuatan pembuktian jaminan fidusia.

Didalam Pasal 5 Ayat (1) dan (2) Undang-undang No. 42 Tahun 1999 Tentang Jaminan Fidusia menyebutkan: Pasal (1)“ "Pembebanan Benda Dengan Jaminan Fidusia Dibuat Dengan Akta Notaris Dalam Bahasa Indonesia Dan Merupakan Akta Jaminan Fidusia” Pasal (2) "Terhadap Pembuatan Akta Jaminan Fidusia sebagaimana dimaksud Dalam Ayat (1), Dikenakan Biaya Yang Sebesarmya Diatur Lebih Lanjut Dengan Peraturan Pemerintah" Didalam pembuatan akta jaminan Fidusia meliputi:

a) Identitas pihak pemberi dan penerima fidsiaa;

b) Data perjanjian pokok yang dijamin fidusia;

c) Uraian mengenai Benda yang benda yang menjadi objek jaminan fidusia;

d) Nilai penjamin dan

e) Nilai benda yang menjadi objek jaminan fidusia.

Dari uraian diatas untuk pembuatan akta fidusia harus dilakukan dihadapan notaris atau pejabat yang berwewenang. Hasil wawancara penulis dilapangan dengan Muhamad Rofii sebgai salah satu debitor yang melakukan kredit motor melaui pembiyaan dengan PT. FIIFGROUP Cabang Selong Lombok Timur menyatakan tidak pernah membuat perjanjian apapun dihadapan notaris, melainkan hanya menandatangani dokumen kontrak perjanjian sebagai debitor, untuk menyepakati kewajiban sebagai debitor kepada kreditor dan konsekuensi bila melakukan wanprestasi. Bila dilihat dari Undang-Undang Jminan Fidusia yang mensyaratkan untuk melakukan pembuatan akta oetentik dihadapan notaris maka, dapat disimpulkan kontrak yang ditandatangani yang berisi ketentuan hak dan kewajiban debitor dan kreditor dikatakan merupakan akta dibawah tangan. Menurut penulis, jika situasi diatas dilihat dari satu sisi saja akan terlihat cacat atau batal demi hukum karna kontrak perjanjian dibuat sepihak dengan ketentuan yang baku dibuat oleh perusahaan tanpa ada kesekepakatan kedua belah pihak. Ketentuan-ketentuan dalam 
kontrak dan aturan-aturan yang disyaratkan dalam ketentuan Undang-Undang bertujuan untuk mengatur kebaikan kedua belah pihak, namun dalam ketentuan syarat syah akta oetentik yang harus dibuat, dan dihadapan pejabat yang berwewenang. Berpijak dari kontrak yang dibuat oleh FIFGROUP Cabang Selong Lombok Timur tentang Akta Fidusia untuk menghadirkan Sertifikat Fidusia ini dilakukan melalui proses Surat Kuasa Fidusia yang ditandatangani oleh debitor kepada pihak PT. FIFGROOP Cabang Selong Lombok Timur saat melakukan penandatanganan kontrak.

Dari hasil wawancara penulis dengan Muhammad Rofii dan debitor pengisi kuisioner (data terlampir) selaku debitor dan narasumber menyatakan tidak ada rasa keberatan dengan isi kontrak perjanjian yang ditandatangani yang disiapkan oleh PT. FIIF GROOP, dalam hal ini justru debitor merasa dibantu dengan adanya lembaga pembiayaan FIFGROUP bilamana permohonan pengajuan kredit debitor diterima. Dalam hal ini debitor justru merasa pemenuhan keperluan hidupnya menjadi mudah dan pengembangan usaha dan perekonomian keluarga dapat teratasi.10 (Sepuluh), (data terlampir) pengisi kuisioner yang diwawancarai penulis menyatakan, tidak keberatan dengan penyerahan hak kuasa Fidusia kepada PT. FIFGROUP Cabang Selong Lombok Timur, karna ingin proses yang cepat dan tidak memakan waktu yang lama.

Selanjutnya setelah melalui proses pembuatan akta Fidusia, maka benda yang menjadi objek fidusia wajib didaftarkan melalui kantor pendaftaran fidusia.

Pendaftaran Fidusia diatur dalam pasal 13 dan 14 Undang-Undang No. 42 Tahun 1999 Tentang Fidusia yakni:

Pasal 13 Ayat (1) "Permohonan pendaftaran jaminan fidusia dilakukan oleh penerima jaminan fidusia dilakukan oleh penerimaan fidusia, kuasa atau wakilnya dengan melampirkan pernyataan pendaftaran jaminan fidusia"

Ayat (2) "Pernyataan pendaftaran sebagaimana dimaksud dalam ayat (1) memuat; identitas pemberi dan penerima fidusia, tanggal, nomor akta jaminan, nama, dan tempat kedudukan notaris yang membuat akta jaminan fidusia" Ayat (3) "Kantor pendaftaran Fidusia memuat jaminan Fidusia dalam buku daftar fidusia pada tanggal yang sama dengan tanggal penerimaan permohonan pendaftaran.

pasal 14 ayat (1) "Kantor pendaftaran fidusia menerbitkan dan menyerahkan kepada penerima fidusia sertifikat jaminan fidusia pada tanggal yang sama dengan tanggal penerimaan permohonan pendaftaran" Pendaftaran jaminan fidusia pada dasarnya mengatur kepentingan dari kedua belah pihak, khususnya bilama debitur melakukan wanprestasi, dan atas kewajibannya untuk pemenuhan prestasinya melalui eksekusi terhadap kreditur.

Dari uraian diatas dapat dijelaskan penulis, proses kesepakatan yang dibuat oleh FIF GROUP dengan syah dan mengikat karna adanya penandatanganan penyerahan kuasa fidusia untuk menyerahkan kepada pihak FIFGROUP Cabang Selong Lombok timur oleh debitor, dan bila di lihat dari Sumbersumber hukum di Indonisia adalah perjanjian dan Undang-Undang, yang dimana memiliki hukum perikatan berdasarkan KUHperdata yakni:

a) Perikatan yang timbul dari persetujuan (perjanjian).

b) Perikatan yang timbul dari undang-undang.

c) Perikatan yang terjadi bukan perjanjian tetapi perbuatan melanggar hukum (onrechmatige daad).

Didalam melakukan perjanjian ada beberapa asas yang menyebabkan syahnya perikatan tersebut yaitu.

1) Asas Konsensualisme yang diatur dalam pasal 1320 KUHperdata dan terdapat empat syarat untuk syahnya suatu perjanjian sebgai berikut:

a. Sepakat mereka yang mengikatkankan dirinya.

b. Kecakapan untuk membuat suatu perjanjian.

c. Suatu hal/ obyek tertentu dan.

d. Suatu sebab yang halal.

2) Asas Pacta Sunt survanda. Berkaitan dengan akibat hukum perjanjian pasal 1338 ayat (1) KUHperdata sebagai berikut: 
a. Perjanjian yang dibuat secara sah berlaku sebagai Undang-Undang bagi mereka yang mengikatkan dirinya.

b. Para pihak harus menghormati perjanjian dan melaksanakannya karena perjanjian itu merupakan kehendak bebas para pihak.

c. Asas kebebasan berkontrakPasal 1338 KUHperdata "semua perjanjian yang di buat sah berlaku sebagai undang-undang bagi mereka yang membuatnya" Ketentuan tersebut memberikan kebebasan perapihan untuk:

1) Membuat atau tidak membuat perjanjian

2) Menentukan isi perjanjian, pelaksanaan dan persyaratannya

3) Mengadakan perjanjian dengan siapapun

4) Menentukan bentuk perjanjian yaitu tertulis atau lisan

Perjanjian diantara para pihak berdasarkan asas "kebebasan berkontrak" yaitu perjanjian antara pihak perusahaan financial sebagai kreditur dan pihak konsumen sebagai debitur. Sejauh yang tidak bertentangan dengan prinsip-prinsip hukum yang berlaku, maka perjanjian seperti itu syah dan mengikat secara penuh.Hal ini dilandasi pada ketentuan dalam pasal 1338 ayat 1 KUHperdata yang menyatakan bahwa suatu perjanjian dibuat secara sah berlaku sebagai Undang-Undang bagi yang membuatnya.

2. Prosudural Eksekusi Benda Objek Jaminan

Fidusia Pada PT. FIFGROOUP Cabang

Selong Lombok Timur

Ayat (1) "Dalam sertifikat jaminan fidusia sebagaimana dimaksud dalam pasal 14 ayat (1) dicantumkan kata-kata" Demi Keadilan Berdasarkan Ketuhanan Yang Maha Esa',

Ayat (2) "sertifikat jaminan fidusia sebagaimana dimaksud dalam ayat (1) mempunyai kekuatan eksekutorial yang sama dengan putusan pengadilan yang telah memperoleh kekuatan hukum tetap.

Ayat (3) "Apabila debitor cidera janji, penerima fidusia mempunyai hak untuk menjual benda yang menjadi objek jaminan fidusia atas kekuasaannya sendiri"

Dari uraian diatas penulis menarik kesimpulan bahwa dalam hal eksekusi pihak FIF GROUP berkuasa penuh untuk mengeksejusi objek barang jaminan fidusia demi keadilan sesuai dengan pasal 15 ayat (1), (2), dan (3).

Pihak FIFGROUP dalam melaksanakan eksekusi juga berpedoman pada pasal 27 ayat (1) dan (2), Dan pasal 30 (ayat 1), Undang-Undang Jaminan Fidusia No. 42 tahun 1999.

Pasal 27 ayat (1) "Penerima fidusia memiliki hak yang didahulukan terhadap kreditor lainnya" Pasal 27 ayat (2) "Hak yang didahulukan sebagaimana dimaksud dalam ayat (1) adalah hak penerima fidusia untuk mengambil pelunasan piutangnya atas hasil eksekusi onjek benda jaminan fidusia.

Pasal 30 berbunyi: "pemberi fidusia wajib menyerahkan benda objek jaminan fidusia dalam rangka pelaksanaan eksekusi jaminan fidusia." Didalam proses eksekusi pada PT. FIFGROUP akan melalui beberapa tahapan yaitu teguran secara langsung kepada debitor saat kolektor datang menagih, tentang kewajiban debitor untuk membayar prestasinya, itu berlaku saat enol (0) bulan sampai dengan masuk bulan ketiga (3). Bulan ketiga (3) hingga maksimal bulan keenam (6). Selanjutnya akan diberikan surat peringatan, surat peringatan tidak tertulis dan tertulis dari surat peringatan satu (1) sampai tiga (3) dalam hal ini FIFGROOP Cabang selong Lombok Timur sudah berupaya memberikan kelonggaran waktu untuk memenuhi i'tikad baik debitur untuk memenuhi prestasinya atas wanprestasi yang dilakukan. Upaya ini dilkukan oleh FIF GROUP untuk menjalankan hak perlindungan konsumen dalam hal mendapatkan sikap yang baik kepada konsumen dari pihak perusahaan. Didalam asas hukum fidusia sifat mendaku tidak boleh dimiliki oleh pihak kreditur artinya menguasai benda objek fidusia secara langsung atau secara penuh. Menurut nara sumber Heri Kuswato menyatakan, atas hal itu pihak FIFGROOP tidak langsung melakukan eksekusi penuh, namun akan melaluiupayaupaya teguran lisan, surat peringatan (1) (2) dan (3), letigasi atau mediasi.

PT. FIFGROUP dalam menjalankan prosudural pelaksanaan eksekusi benda objek jaminan fidusia setelah melakukan tahapan tersebu diatas, kemudian pihak FIFGROUP Cabang Selong Lombok timur menyerahkan 
kepada pihak depolektor/profesional kolektor yang dinaungi oleh PT dan CV yang legal atau berbadan hukum dan mendapatakan izin oleh Menteri Hukum dan Hak Asasi Manusia (data terlampir).

Sesuai Dengan Peraturan Kapolri No. 8 Tahun 2011 Dalam hal ini nara sumber Heri Kuswanto menjelaskan menyatakan bahwa terkait eksekusi yang dilakukan syah karna mengunakan serah kuasa kepada PT/CV yang berbadan hukum dan mendapatkan izin dari menteri hukum dan hak asasi manusia

Dalam pasal 3 Peraturan Kepala Kapolri No. 8 Tahun 2011 BAB I Ketentuan Umum Menjelaskan perinsip perinsip peraturan yang meliputi:

a. Legalitas, yaitu pelaksanaan pengamanan eksekusi benda jaminan fidusia harus sesuai dengan ketentuan peraturan perundang undangan.

b. Nesesitas, yaitu pengamanan eksekusi jaminan fidusia fidusia diberikan berdasarkan penilaian situasi dan kondisi yang dihadapi

c. Proporsionitas, yaitu pengamanan eksekusi jaminan fidusi dilaksanakan dengan memperhitungkan hakikat ancaman yang dihadapi dan pelibatan kekuatan.

d. Akuntabilitas, yaitu pelaksanaan pengamanan eksekusi jaminan fidusi dapat dipertanggungjawabkan.

e. Dari urain prinsip Peraturan Kepala Kapolri No. 8 Tahun 2011 diatas menjelaskan tingkatan eksekusi yang dimana melibatkan kepolisian bilamana ada pada tahapan yang sangat sulit atau tahapan tinggi.

Pihak PT. FIFGROUP menjalin kerja sama dengan PT atau CV yang legal (dokumen terlampir) sesuai dengan peraturan kapolri No.8 Tahun 2011. Pasal 9 Ayat (1):

"Dalam hal penerima menunjuk pihak ketiga untuk melaksanakan eksekusi, permohonan pengamanan eksekusi diajukan dengan melampirkan perjanjian kerja sama eksekusi jaminan fidusia antara penerima jaminn fidusi dan pihak yang ditunjuk",

Selanjutnya PT. FIF GROUP dan PT atau CV yang menaungi depkolektor dan profesional kolektor membuat hubungan hukum dan perjanjian tertulis yang dibubuhi materai dan ditanda tangani oleh kedua belah pihak dengan menyerahka kuasa kepada PT yang menaungi depkolektor dengan melengkapi persyaratan, data pemohon kredit, surat peringatan kepada debitur, sertifikat fidusia, dan Identitas pemberi fidusia (debitor).

Sebelum melakukan eksekusi pihak debitur oleh depkolektor, pihak eksekusi atau depkolektor akan diberi surat tugas oleh PT yang menaungi. Proses selanjutnya depkolektor akan menandatangi rumah debitur dengan penyelesain secara damai satu (1) sampai dengan maksimal (2) kali, jika dengan proses ini tidak berhasil untuk mengamankan objek benda jaminan fidusia untuk menuntut prestasi debitor atas wanprestasinya, maka proses terakhir yang akan dilakukan adalah mengeksekusi objek benda jaminan fidusia dimanapun dilihat atau ditemukan.

Pada saat objek jaminan fidusia sudah dieksekusi oleh depkolektor, maka akan melalui beberapa tahapan yakni:

1. Dibawa kekantor cabang terdekat untuk diberikan penjelasan kepada debitor, tentang penyebab objek jaminan fidusia itu diamankan atau dieksekusi guna untuk menuntut prestasi debitur atas kewajibannya.

2. Diberikan surat pernytaan untuk penyelesain wanprestasi.

3. Jika debitur kembali tidak menepati prestasinya, maka akan diberikan surat peringatan dengan cara ditelpon oleh pihak kantor FIFGROUP dan diberikan pemberitahuan tertulis.

4. Tindakan terakhir adalah pelelangan.

Didalam poin empat (4) di atas FIFGROUP akan menyurati untuk pemberitahuan pelelangan benda objek jaminan fidusia, dalam hal pelelangan, itu akan dilakukan satu kali dalam satu bulan pada akhir bulan dan melewati satu pintu dengan mengabungkan semua benda hasil eksekusi antara cabang FIFGROUP mataram, lombok barat,lombok tengah dan lombok timur.

Dari uraian diatas penulis dapat menjelaskan proses prosudural eksekusi di FIFGROUP Cabang selong lombok timur tidak dilangsungkan oleh pihak perusahaan melainkan serah kuasa eksekusi kepada 
kepada PT/CV yang menaungi depkolektor. Depkolektor bertugas menjalankan mengeksekusi atas surat tugas dari PT/CV yang menaungi para depkolektor. Secara prosudural $\mathrm{PT} / \mathrm{CV}$ tempat bernanung para depkolektor legal sehingga dapat dinyatakan depkolektor berhak untuk mengeksekusi benda objek jaminan fidusia (dokumen terlampir).

Di dalam Undang-Undang Jaminan Fidusia No.42 Tahun 1999 Pasal 34 menyebutkan:

ayat (1) "Dalam hal hasil eksekusi melebihi nilai penjamin, penerima fidusia wajib mengembalikan kelebihan tersebut kepada pemberi fidusia"

Ayat (2) "Apabila hasil eksekusi tidak mencukupi untuk pelunasan utang, debitor tetap bertanggung jawab atas utang yang belum dibayar"

Dari uraian di atas, penulis dapat menarik kesimpulan bahwa jika terjadi eksekusi benda objek jaminan fidusia atas wanprestasi yang dilakukan, maka akan dilaksankan melalui serah kuasa kepada PT yang menaungi depkolektor. FIFGROUP Cabang Selong Lombok Timur melaksanakan eksekusi dengan penyerahan kuasa karna dalam struktur organisasi FIFGROUP, tidak memiliki strutuktur khusus untuk pelaku eksekusi sehingga pihak FIFGROOP Cabang Selong Lombok Timur melakukan kerja sama dengan PT atau CV yang menanungi depkoletor/profesional kolektor yang legal (ketengan terlampir) untuk pengeksekusian objek benda jaminan fidusia.

Menurut penulis proses eksekusi benda objek jaminan fidusia pada dasarnya hanya untuk menuntut prestasi atas wanprestasi yang dilakukan oleh debitur dengan tujuan menghasilkan kesepakatan untuk penyelesaian.

B. Hambatan-Hambatan Prosudural Eksekusi

Benda Objek Jaminan Fidusia Di PT.

FIFGROOP Cabang Selong Lombok

Timur.

1. Hambatan Prosudural Legalitas Benda Objek Jaminan Fidusia Di PT. FIFGROUP

Cabang Selong Lombok Timur.

Berdasarkan hasil penelitian penulis pada PT. GROUP Cabang Selong Lombok Timur bahwa hambatan-hambatan yang dihadapi dalam prosudural penjaminan secara fidusia adala:

a. Adanya biayaya pembuatan akta notaris dan biaya-biaya yang berkaitan dengan penjamin fidusia yang dimana debitor merasakan berat sehingga membutuhkan waktu yang lama dalam hal kesepakatan antara debitor dan kreditor.

b. Adanya persyaratan yang kurang lengkap dari debitor untuk menguraikan jenis, merek dan kualitas obyek fidusia yang wajib diuraikan dalam akta jaminan fidusia.

c. Membutuhkan waktu yang lama untuk mengurus ke notaris, dan objek benda baru bisa keluar hingga satu bulan, sementara pihak debitur ingin obyek cepat dikeluarkan atau direalisasi.

d. Eksekusi melalui lembaga parate eksekusi, tidak pernah efektif disebabkan debitor tidak pernah secara cepat menyerahkan barangnya untuk dijual atas wanprestasi yang dilakukan.

Dari uraian di atas menjelaskan tingkat kesulitan kreditur dalam hal menjalankan semua ketentuan prosudural benda objek jaminan fidusia dengan pembebanan diberikan kepada pemberi fidusia yang dimana merasa keberatan dalam hal pembiyayaan dan proses yang dianngap memakan waktu oleh debitor. Dari hasil wawancara penulis dengan debitur yang rata-rata lebih memilih menyerahkan hak kuasa fidusia kepada pihak kreditur untuk mengurus hal-hal yang terkait, menjadi ketentuan dalam prosudural jaminan benda objek fidusia.

2. Hambatan Prosudural Eksekusi Benda Objek Jaminan Fidusia Di PT. FIFGROUP Cabang Selong Lombok Timur.

Didalam proses prosudural eksekusi benda yang menjadi objek jaminan fidusia, hambatan-hambatan yang sering dihadapi oleh PT. FIFGROUP Cabang Selong Lombok Timur saat pengeksekusian oleh pihak ke tiga yang diberi kuasa kepada PT yang menaungi depkolektor (legal) atas wanprestasi yang di lakukan debitur, sering mengalami hambatan dari pihak debitur seperti:

1. Tidak adanya i'tikad baik oleh debitur untuk menyerahkan barang objek jaminan 
fidusia demi menuntut prestasi debitur atas wanprestasi yang dilakukan.

2. Banyak beredarnya mafia motor yang menyebabkan hilangnya objek yang menjadi objek benda eksekusi jaminan fidusia.

3. Terjadi gadai benda objek jaminan fidusia di bawah tangan oleh pihak debitur ke pada tangan ketiga dan seterusnya.

4. Berkurangnya nilai benda objek jaminan fidusia, sebab benda objek jaminan tidak seperti semula (diperetel).

Dari urain penjelasan diatas sudah sangat jelas dimana hal-hal prosudural kelengkapan persyaratan pendaftaran sertifikat fidusia terpenuhi (dokumen terlampir).Dalam peneltian dilapangan penulis menemukan terkait sertifikat fidusia beberapa pernyataan debitor yang diwawancarai memberikan pernyataan tidak pernah melakukan penanda tanganan akta otentik didepan pejabat Notaris sesuai dengan yang diatur Undang-Undang Jaminan Fidusia No. 42 Tahun 1999, dan tidak mengerti tentang sertifikat fidusia.

Adanya dokumen Sertifikat fidusia dalam hal fidusia ( contoh dokumen terlampir), penulis menemukan satu permasalahan yang muncul bahwa adanya sertifikat fidusia, disebabkan debitor menandatangani pemberian surat kuasa kepada kreditur untuk mewakili pengurusan sertifikat akta fidusia,yang dimana saat melakukan tanda tangan kontrak perjanjian yang diberikan oleh pihak financial PT. FIFGROUP Cabang Selong Lombok Timur tidak semua mengetahui adanya penyerahan hak kuasa fidusia oleh debitor selaku (pemberi fidusia) kepada kreditor selaku( penerima fidusia).

Peristiwa diatas justru tidak berpengaruh pada beberapa konsumen yang diwawancarai karna justru merasa dibantu dengan pengurusan pendaftaran sertifikat fidusia tersebut, karna hal yang paling mendasari bagi debitur adalah pemberian kredit barang ataupun modal oleh FIFGROUP sangat membantu masyarakat dalam hal pemenuhan kebutuhan debitur untuk memajukan taraf memajukan perekonomian keuangan mereka. Dalam hal ini FIFGROUP sebagai pihak kreditur secara tidak langsung membantu masyarakat

dalam hal prembangunan ekonomi.

Selanjutnya untuk hambatan prosudural eksekusi benda objek jaminan fidusia penulis menyimpulkan permasalahan yang diuraikan diatas dalam hambatan prosudural eksekusi, sangat merugikan pihak perusahaan dan menghambat proses eksekusi seperti:

a. Tidak adanya i'tikad baik dari oknum yang melakukan wanprestasi kepada pihak kreditur sedangkan kreditur sudah beruapaya untuk memberikan teguran melalui pihak kolektor, komfirmasi melalui tlp dan surat peringatan tertulis.

b. Wanprestasi yang dilakukan oleh oknum debitor seperti; menghilangkan benda objek jaminan fidusia, mengubah, membongkar objek jaminan fidusia (mempretel), menggadai di bawah tangan, jelas sanggat merugikan perusahaan dan melanggar ketentuan dari kontrak yang disepakati oleh debitor kepada kreditur untuk menjaga objek jaminan fidusia selama pembayaran kredit belum diselesaikan sesuai dengan yang ditentukan dalam kontrak. Sudah sangat jelas, yang berisi bahwa titel kepemilikan akan kembali kepada debitur bilama prestasi debitur melunasi pembayaran kepada kreditur terpenuhi.

Dari uraian tentang prosudural eksekusi benda objek jaminan fidusia dan hambatannya-hambatanya, penulis akan menguraikan hubungan sosial dan hukum antara kreditur dan debitur melalui penjelasan kuisioner yang dijelaskan melalui daftar tabel.

Hasil penelitian korespondesi yang dimana dilakukan oleh penulis dengan tekhnik populasi dan sample dimana sasarannya adalah debitor yang melakukan kredit pada PT. FIFGROUP Cabang Selong Lombok Timur yang dengan dilenkapi kritik dan saran ( Dokumen Terlampir).

Formulasi pilihan jawaban untuk kuisioner sebagai berikut :

Sangat Tidak Puas.
a. Tidak Puas.
b. Cukup puas
c. Puas

Tabel I: 
Total jumlah pertanyaan 6 dan jumlah responden secara total 10 dalam menjawab kuisioner.

\begin{tabular}{|c|c|c|c|}
\hline No. & Nama Kreditur & Total pertanyaan & Total Akumulasi \\
\hline 1. & Tomi Iswanto & 6 & 10 \\
\hline 2 & M. Rofii & 6 & 10 \\
\hline 3 & Inaq. Ripaah & 6 & 10 \\
\hline 4 & Marzoan & 6 & 10 \\
\hline 5 & Muhammad Ali & 6 & 10 \\
\hline 6 & Sumardan & 6 & 10 \\
\hline 7 & Sri Tuti Rahayuni & 6 & 10 \\
\hline 8 & Juni Riskan & 6 & 10 \\
\hline 9 & Iwan & 6 & 10 \\
\hline 10 & Sulhidiyah & 6 & 10 \\
\hline
\end{tabular}

Menurut rumus Spearmen's ini, pertama-tama disusun posisi (rank), dari masing-masing debitur dalam tata urut yang ditentukan menurut total pertanyaan atau di tentukan dengan total akumulasi hasil pertanyaan. Setelah itu di temukan hasil antara jumlah debitur dengan hasil akumulasi pertanyaan setelah jumlah dikalikan dapat dibuatkan rumus:

$$
\mathrm{r}=1-\frac{6 \sum \mathrm{D}^{2}}{\mathrm{~N}^{3}-\mathrm{N}}
$$

Tabel II: Perhitungan rumus penulis dari petunjuk tabel I

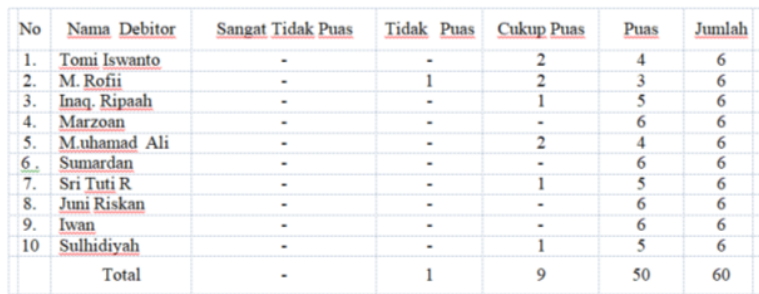

Ket: $6=$ Jumlah pertanyaan

$\mathrm{N}=$ Total kode nilai setiap pertanyaan

$\mathrm{D}^{2}=$ Jumlah Sample Debitur

$$
\begin{aligned}
& r=1-\underline{6 \sum D} \\
&=1- \frac{6 \times 60}{10^{3}-10} \\
&=1-\underline{360} \\
& 990 \\
&=0,64
\end{aligned}
$$

Sudah menjadi kesepakatan bahwa derajat besarnya hubungan antara kedua variabel (disini disebut koefisieni) selalu diukur dengan hasil yang dinyatakan dalam lambang bilangan antara: 0,00 dan 1,00 atau (1,00). Apabila diperoleh hasil 0,00 berarti hubungan antara dua variabel tersebut tidak ada, dan apabila angka yang diperoleh adalah 1,00 atau -1,00 hubungan itu ada secara sempurna. dari hasil tersebut jelaslah bahwa variabel "kepuasan debitur" berhubungan secara positif dengan pihak FIFGROUP Cabang Selong Lombok Timur dalam melakukah hubungan hukum dengan asas kepercayaan, terlihat dari total akumulasi dari pertanyaan yang dijawab oleh debitur. Angka 0,64 menandakan hubungan antara kreditur, debitur dalam persentase rumus diatas cukup sempurna. Penjelesan dalam hasil mendekati angka 1,00, jelas bahwa derajat antara dua variabel tersebut cukup besar dan harus terus berupaya untuk mencapai hubungan hukum yang sempurna antara FIFGROUP Cabang Selon Lombok Timur dengan phak debitor melalui segala bentuk kebijakan oleh pihak PT. FIFGROUP Cabang Selong Lombok Timur dan pihak debitur dalam menujukan prestasinya.

Dari hasil pilihan debitur yang menjadi sample untuk memberikan beberapa jawaban pada kuisioner yang disiapkan penulis, debitur dalam hal melakukan kredit kepada kreditur dengan pengajuan permohonan pinjaman atau kredit dengan ketentuan syarat yang diberikan oleh kreditur merupakan keinginan yang dimana dalam melakukan kredit, debitur sangat merasa terbantu dalam memenuhi kebutuhannya baik melalui pinjaman kredit modal atau barang.

Dalam melakukan kredit terkadang debitor tidak dapat memenuhi prestasi, baik dalam awal perjanjian fidusia itu dilakukan hingga proses berjalannya pemenuhan kewajiban debitor untuk memenuhi kewajibannya kepada kreditor. Dalam hal pemenuhan prestasi kepada kreditur terkadang ada oknum dari debitur yang lalai dalam hal kewajibannya untuk pemenuhan prestasi dengan menyelesaikan setoran atau angsuran yang sudah disepakati dari debitor kepda kreditur dimana diatur dalam Pasal 7 UndangUndang No. 8 Tahun 1999 Tentang perlindungann konsumen yang memuat kewajiban konsumen terhadap perusahaan atau pemilik modal. Namun tidak dapat dihindari dalam prakteknya wanprestasi yang dilakukan oleh pihak debitur berbuntut pada eksekusi benda yang menjadi objek jaminan benda fidusia. Prosudural eksekusi juga akan melalui tahapan tahapan prosudural eksekusi benda jaminan fidusia yang di atur dalam UndangUndang No. 42 Tentang Jaminan Fidusia. 
Dalam peristiwa eksekusi sering sekali beakhirnya dengan, terjadi permasalahanpermsalahan baik dari pihak debitor yang merasa berhak atas benda objek jaminan fidusia, dan depkolektor yang menjalankan tugas proses eksekusi.

Hasil kuisioner debitur dapat memberikan penjelasan bahwa debitur yang melakukan hubungan fidusia dengan ktreditur menyatakan eksekusi yang dilakukan oleh depkolektor merupakan suatu kewajaran, karna tidak dapat memenuhi kewajiban nya untuk memenuhi prestasinya (Dokumen Terlampir).

Menurut uraian diatas penulis dapat memberikan penjelasan bahwasannya pihak yang merasa keberatan dan tidak mendapat keadilan, atas pengeksekusian benda objek jaminan fidusia adalah pihak yang melakukan wanprestasi. Melaui penelitian dilapangan baik melalui sample debitur, wawancara, penulisan kritik, saran dari pihak debitur untuk permasalahan kredit dengan pihak FIFGROUP para debitur merasakan satu hal dampak positif secara sosial dengan adanya PT. FIFGROUP Cabang Selong Lombok Timur, yaitu memudahkan para debitur dalam memenhi kebutuhan hidupnya, mendapatkan modal pinjaman, yang dimana bila diakomodir secara individual akan butuh waktu yang lama untuk mengumpulkan dana tersebut. Para debitur juga banyak tidak mengetahui tentang prosudural yang sesuai dengan ketentuan Perundang-Undangan yang ada, baik tentang penyerahan hak kuasa maupun prosudural leglitas formal dan prosudural proses Eksekusi.

Dari uraian penjelasan prosudural eksekusi benda objek jaminan fidusia dan hambatan-hambatanya terkait dengan PT. FIFGROUP Cabang Selong Lombok Timur sebagai lokasi peneltin, dan hasil penelitian lainnya, penulis dapat memafarkan sebagai berikut:

1. Gambaran Umum PT. FIFGROUP

Sejarah singkat PT. Federal Internasional Fnance

PT. Federal internasional finance (F.I.F) merupakan anak perusahaan PT. Astra Internasional Tbk., dan tergabung dalam The Astra FinancialServices. Perusahan yang lahir pada Bulan Mei Tahun 1989 dengan nama PT. Mitrapusaka Arta Finance yang merupakan perusahaan pembiyaan yaitu badan usaha diluar bank dan lembaga keuangan bukan bank yang khusus didirikan untuk melakukan lembaga pembiyaan. Berdasarkan ijin usaha yang diperolehnya, maka Perseroan bergerak dalam bidang sewa guna usaha, anjak piutang dan pembiayaan konsumen. Pada tahun 1991, Perseroan merubah nama menjadi PT Federal International Finance (PT. FIF) FIF juga merupakan lembaga pembiyaan konsumen (Consumers Finance Company) yaitu badan usaha yang melakukan pembiyaan pengadaan barang untuk kebutuhan konsumen dengan sistim pembayaran angsuran secara berkala. Selain itu FIF juga disebut lembaga pembiyaan yaitu kegiatan pembiyaan dalam bentuk penyedian dana atau modal dengan tidak menarik dana secara langsung dari masyarakat. Namun seiring dengan perkembangan waktu dan guna memenuhi permintaan pasar, Perseroan mulai memfokuskan diri pada bidang pembiayaan konsumen secara retail pada tahun 1996.Ketika badai krisis moneter mulai menerpa pada tahun 1997, saat itu pula merupakan titik balik bagi Perseroan untuk melakukan konsolidasi internal dalam rangka persiapan menuju ke suatu system komputerisasi yang tersentralisasi dan terintegrasi.Walaupun krisis moneter tersebut berkembang menjadi krisis multidimensi, namun berkat kerja keras jajaran Direksi beserta seluruh karyawan Perseroan tetap dapat berjalan. Perseroan yang mayoritas sahamnya dimiliki oleh PT. Astra International Tbk ini, tahun demi tahun lebih memantapkan dirinyas ebagai perusahaan pembiayaan terbaik dan terpercaya di industrinya, sehingga pada saat penerbitan obligasi pertama tahun 2002 hingga obligasi kelima tahun 2004 mendapatkan tanggapan yang positif dari para investor dan pada tahun 2004 hingga 2017 ini dan berubah nama menjadi PT. FIFGROUP. FIF sangat dikenal pada era saat kredit motor dan kredit mobil menerjang segenap sudut kota dan sudut pelosok desa, bisa dipastikan dimanapun orang kenal FIF yang sekarang menjadi FIFGROUP.

2. Gambaran Umum Profile PT. FIFGROUP Cabang Selong Lombok Timur 
FIFGROUP adalah grup manajemen dari beberapa perusahaan yang memiliki unit bisnis yang bebeda-beda.FIFGROUP Saat ini menaungi FEDERAL Internasional Finance dan PT. Astra Multi Finance.Jasa layanan pembiayaan sepeda motor Honda, baik motor baru maupun seken yang berkualitas.

FIFGROUP merupakan manajemen dari beberapa perusahaan yang memiliki unit bisnis yang berbeda-beda. FIFGROUP saat ini menaungi PT Federal International Finance dan PT Astra Multi Finance FIFGROUP bergerak dibisnis layanan pembiayaan. FIFGROUP hadir untuk mengakomodir keanekaragaman kebutuhan masyarakat Indonesia dengan senantiasa berpegang pada prinsip inovasi dan kreativitas.Mengubah tantangan menjadi peluang adalah landasan pemikiran yang membuat FIFGROUP terus berkembang.

a. FIFGROUP bergerak dibisnis layanan pembiayaan dengan nama merek berikut:

1. FIFASTRA

2. SPEKTRA

3. Bagan kelembagaan PT. FIFGROUP Cabang Selong Lombok Timur Tahun 2017.

\section{BAGAN STRUKTUR PT. FIFGROUP} CABANG SELONG

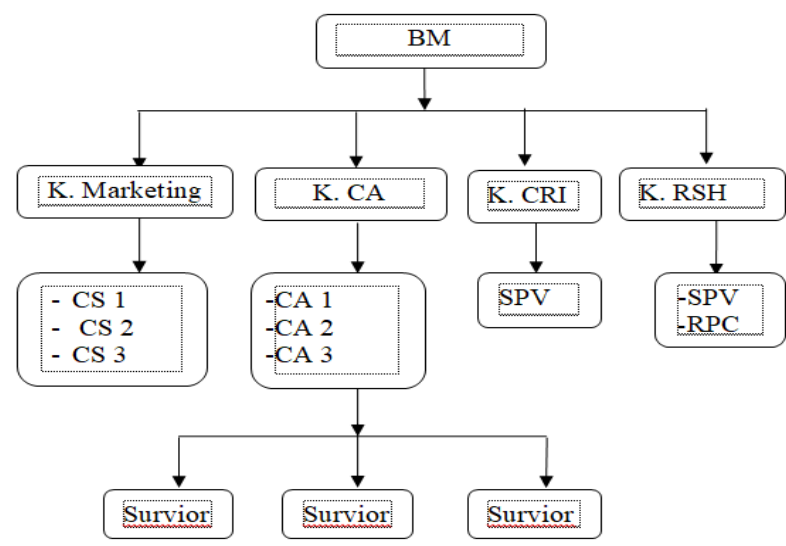

Uraian tugas (Job Description) bagian atau unit kerja PT. FIFGROUP Cabang Selong Lombok Timur sebagai berikut:

a. Manager Bertangung jawab penuh (Back Up Control) untuk semua job discription bawahan.

b. Kepala Marketing bertugas mengakomodir setiap laporan custamer service untuk dilaporkan kepada Brand Manager (BM) c. Back Up laporan dari kredit analis, dari Surveor untuk dilaporkan kepada BM.

d. CRI Back Up laporan tagihan keterlambatatan debitur dari SPV ke pada BM.

e. RSH Back Up laporan tagihan penindakan keterlambatatan debitur dari SPV dan RVC ke pada BM.

f. kredit Analis (CA) memberi acc atas pengajuan kredit debitur dengan menganalisa hasil survey dan mengimputnya kesistem untuk di acc oleh BM

g. Surprayer bertugas mengunjungi, menganalisa debitur dengan mendatangi rumah debitor untuk disurvey dan dilaporkan kepada CA

h. SPV bertugas melaporkan setiap tagihan berupa kredit macet yang ditanggulangi kepada atasan untuk dilaporkan kepada BM, SPV terbagi menjadi dua SPV tagihan 0 bulan sampai 1bulan dan SPV tagihan 2 bulan sampai 5 bulan.

i. RPC bertugas melaporkan setiap tagihan berupa kredit macet yang di tanggulangi kepada atasan untuk dilaporkan kepada BM, adapun kredit macet atau wanprestasi yang ditanggulangi 6 bulan keatas, yang tak terhingga waktu keterlambatannya.

3. Gambaran umum latar Pendidikan dan Mata Pencaharian Masyarakat Lombok Timur

Masyarakat lombok timur merupakan masyarakat yang rata-rata mata pencahariannya adalah bertani. Potensi sumber daya manusia dikabupaten lombok timur didasarkan atas ketersedian tenaga kerja serta keahlian yang dimiliki oleh rata-rata tenaga kerja yang belum tersalurkan dari masing masing kecamatan yang ada sekitar 5-10 0 0 dengan rata-rata pendidikan terakhir Sekolah Dasar (SD), Sekolah Menengah Pertama (SMP) dan banyak yang putus atau tidak sekolah.

Dengan demikian untuk potensi Sumber Daya Manusia (SDM) di Kabupaten Lombok Timur mayoritas mempunyai keahlian dibidang pertanian dan perdagangan serta ada yang mempunyai keterampilan seperti membuat kerajinan patung,anyaman,tenun dan lain-lain. 
4. Tingkat Pemahaman Masyarakat Lombok Timur Tentang Hukum Khususnya Tentang Fidusia

Dari wawancara yang dilakukan kepada Masyarakat Lombok Timur, khususnya debitor yang melakukan hubungan hukum perdata dengan pihak financial/pihak lesing dengan caran populasi dan sample. Dari 10 (sepuluh) orang yang diwawancarai 3 dari debitor yang memahami tentang Fidusia, sisanya hanya mengetahui hubungan hutang piutang yang dimana debitor hanya mengetahui kewajiban nya untuk membayar hutang dan jika tidak membayar selama berberapa bulan akan dikenakan denda, dan denda yang menjadi objek fidusia akan disita, dieksekusi, atau diamankan.

5. Pelaksanaan Perjanjian Kredit dan Fidusia

Pada PT. FIFGROUP Cabang Selong Lombok Timur

Hukum merupakan kumpulan dari peraturan perundang-undangan yang mengatur tata tertib masyarakat baik individu dengan individu, individu dengan kelompok ataupun kelompok dengan kelompok dalam kepentingan bermasyarakat untuk mencapai rasa keadilan, dan melindungi kepentingan dalam bermasyarakat. Dalam hal ini hukum juga mengatur praktik fidusia dalam hal perjanjian yang diatur dalam Kitab UndangUndang Hukum Perdata (KUHper) dan eksekusi benda objek jaminan fidusia yang diatur dalam undang-undang No. 42 Tahun 1999 Tentang jaminan fidusia.

Sumber-sumber hukum di Indonisia adalah perjanjian dan Undang-Undang, yang dimana memiliki hukum perikatan berdasarkan KUHperdata yakni:

1. Perikatan yang timbul dari persetujuan (perjanjian).

2. Perikatan yang timbul dari UndangUndang.

3. Perikatan yang terjadi bukan perjanjian tetapi, perbuatan melanggar hukum (onrechmatige daad)

Didalam melakukan perjanjian ada beberapa asas yang menyebabkan syahnya perikatan tersebut yaitu

a) Asas konsensualisme yang diatur dalam pasal 1320 KUHperdata dan terdapat empat syarat untuk syahnya suatu perjanjian sebgai berikut:

1) Sepakat mereka yang mengikatkankan dirinya.

2) Kecakapan untuk membuat suatu perjanjian.

3) Suatu hal atau obyek tertentu dan.

4) Suatu sebab yang halal.

b) Asas Pacta Sunt survanda yang berkaitan dengan akibat hukum perjanjian pasal 1338 ayat (1) Kuhperdata sebagai berikut:

1) Perjanjiamn yang dibuat secara sah berlaku sebagai undang undang bagi mereka yang mengikatkan dirinya.

2) Para pihak harus menghormati perjanjian dan melaksanakannya karena perjanjian itu merupakan kehendak bebas para pihak.

3) Asas kebebasan berkontrakPasal 1338 KUHperdata "semua perjanjian yang dibuat sah berlaku sebagai UndangUndang bagi mereka yang membuatnya" Ketentuan tersebut memberikan kebebasan perapihan untuk:

a. Membuat atau tidak membuat perjanjian

b. Menentukan isi perjanjian, pelaksanaan dan persyaratannya

c. Mengadakan perjanjian dengan siapapun

d. Menentukan bentuk perjanjian yaitu tertulis atau lisan

Perjanjian diantara para pihak berdasarkan asas "kebebasan berkontrak" yaitu perjanjian antara pihak perusahaan financial sebagai kreditur dan pihak konsumen sebagai debitur. Sejauh yang tidak bertentangan dengan prinsip-prinsip hukum yang berlaku, maka perjanjian seperti itu sah dan mengikat secara penuh. Hal ini dilandasi pada ketentuan dalam pasal 1338 ayat 1 KUHperdata yang menyatakan bahwa suatu perjanjian dibuat secara sah berlaku sebagai Undang-Undang bagi yang membuatnya .

Dalam memberikan suatu kredit kepada debitur pada PT. FIFGROOP Cabang Selong, pihaknya akan selalu menghadapi risiko yaitu tidak kembalinya uang yang dipinjamkan kepada debitor. Hal ini menyebabkan pihak kreditor sangat hati-hati mulai dari pengajuan kredit ataupun peminjaman modal sampai dengan melunasi kewajiban debitor atau prestasinya. 
Dari hasil wawancara penulis dengan pihak PT. FIFGROOP Cabang Selong Heri Kuswanto, dengan adanya resiko tersebut maka pihak perusahaan mewajibkan adanya barang jaminan sebagai agunan untuk melindungi hak kreditur dalam hal perjanjian Fidusia sesuai dengan Undang-Undang Jaminan Fidusia no. 42 Tahun 1999 untuk mendapatkan kepastian hukum yang jelas.

Dengan diaturnya perjanjian fidusia dalam akta jaminan fidusia secara tidak langsung memberikan pegangan yang kuat bagi kreditur. Kepastian hukum yang dapat secara langsung terlihat pada kepastian hukum kreditur adalah sebagai berikut:

1. Debitor mengajukan permohonan kredit atau pinjaman modal kepada PT. FIFGROOP Cabang Selong Lombok Timur selaku (kreditor).

2. Meneliti surat permohonan tersebut, melakukan penolakan bila debitor masuk kedalam daftar kredit macet atau blacklist dan melihat usahanya berisiko tinggi atau tidak.

3. Survey kelokasi rumah debitor untuk melihat apakah layak atau tidak untuk diberikan kredit dengan menilai kepribadian, kemampuan, kondisi ekonomi dan agunannya.

4. Penanda tanganan surat kontrak perjanjian yang dimana dalam kontrak perjanjanjian itu tertulis keutamaan melindungi hak kreditur, mengacu pada undang-undang jaminan fidusia no. 42 tahun 1999 Tentang Jaminan Fidusia dan penyerahan kuasa untuk pembuatan Akta otentik untuk sertifikat fidusia. Dari hasil penyerahan kuasa oleh pihak debitor kepada pihak kreditor yang disepakati dan ditangani di atas kontrak bermaterai yang akan mewakili penerima Fidusia dalam penanda tanganan sertifikat fidusia.

\section{KESIMPULAN}

Berdsarkan hasil penelitian dan pembahasan, maka penulis menyimpulkan beberapa hal yaitu

1. Proses prosudural eksekusi benda jaminan fidusia pada PT. FIFGROUP Cabang Selong Lombok Timurdilaksanakan sesuai dengan Undang-Undang No,42 Tahun 1999 Tentang Jaminan Fidusia dalam hal prosudural spendaftaran fidusia yang diserah kuasa untuk eksekusi pada PT (Legal) yang bekerja sama dengan PT. FIFGROUP.Sebelum melakukan proses eksekusi dilakukan beberapa tahapan yaitu teguran secara langsung kepada debitor saat kolektor datang menagih, tentang kewajiban debitor untuk membayar prestasinya, itu berlaku saat enol (0) bulan sampai dengan masuk bulan ketiga (3). Bulan ketiga (3) hingga maksimal bulan keenam (6). Selanjutnya akan diberikan surat peringatan, surat peringatan tidak tertulis dan tertulis dari surat peringatan satu (1) sampai tiga (3) dalam hal ini FIFGROOP Cabang selong Lombok Timur sudah berupaya memberikan kelonggaran waktu untuk memenuhi i'tikad baik debitur untuk memenuhi prestasinya atas wanprestasi yang dilakukan Barulah di serahkuasa kepada PT yang menaungi deplokektor untuk proses eksekusi.

2. Hambatan prosudural yang dialami oleh PT. FIFGROUP Cabang Selong Lombok Timur dalam hal hambatan prosudural legalitas karna kurang nya pemahaman masyarakat atau debitur akan pentingnya sadar hukum. sedangkan hambatan dalam proses eksekusi benda objek jaminan fidusia secara prosudural dalam melakukan eksekusi yakni; FIFGROOP atau PT yang mewakili dalam pengeksekusian tidak memiliki i'tikad baik dari pihak debitur yang melakukan wanprestasi untuk menyelesaikan prestasinya atas wanprestasi yang dilakukan.

\section{Saran}

Saran penulis kepada pihak debitor, kreditor, dan PT yang menaungi para depkolektor dan profesional kolektor sebagai berikut:

1. FIFGROUP Cabang Selong Lombok Timur, Setidaknya sebelum melakukan penanda tanganan kontrak perjanjian, debitur diingatkan untuk membaca kontrak perjanjian agar debitor memahami isi dari kontrak yang akan ditanda tangani.

2. Debitur harus lebih teliti dalam menanda tangani kontrak perjanjian fidusia dengan membaca isi kontrak perjanjian dan menanyakan isi dari kontrak perjanjian 
yang sekiranya ada yang tidak difahami oleh debitor, agar menanyakan kepada kreditor. Sehingga tidak terjadi permasalahan-permasalahan yang tidak diinginkan dikemudian hari.

3. Peran serta pemerintah kabupaten lombok timur dalam hal sosialisasi tentang pemahaman hukum secara umum, dan secara khusus tentang fidusia. Yang dimana berguna untuk dapat melindungi hak masyrakat (debitor) dari kepastian hukum, atas perikatan yang dilakukan, dalam melakukan kredit modal ataupun barang terhadap kreditur.Dan untuk mencegah oknum depkolektor atau profesional kolektor yang tidak legal (ilegal), perlu dilakukan monitor atau swiping terutama oleh pihak kepolisian untuk menertibkan, oknum depkolektor yang tidak bertanggung jawab atau ilegal.

\section{DAFTAR PUSTAKA}

A. Buku-buku

Damsar, 2002. Sosiologi Ekonomi. Jakarta. PT. Raja Grafindo Persada

Djunaidi, Ridzki. 2000. Beberapa Permasalahan Hukum Dan Jaminan. Jakarta. BPPN.

Fuady, Munir. 2003. Jaminan Fidusia. Bandung. PT. Citra Aditya Bakti 2002. Hukum Jaminan Utang, Jakarta. PT. Erlangga.

Kamello, Tan. 2006. Hukum Jaminan Fidusia Suatu Kebutuhan Yang Dibanggakan. Bandung. Alumni.

Masjchun Sofwan, Sri Soedewi. 1997. Beberapa Masalah Pelaksanaan Lembaga Jaminan Khusus fiducia Di Dalam Praktek Dan Pelaksanaannya Di Indonesia, Jakarta.Ugm Press.

Moleong, J. Lexy. 1994. Metode Penelitian Kualitatif. Bandung. Remaja Rosda.

Pramono, Nindyo, 2003. Hukum Komersil, Jakarta. Universitas Terbuka (UT)

Satrio, J, 1991. Hukum Jaminan, Hak-hak Jaminan Kebendaan. Bandung. PT. Citra Aditya Bakti. 2002. Hukum Jaminan Hak Jaminan Kebendaan Fidusia, PT. Citra Aditya Bakti.
Sunggoho, Bambang. 2015. Metedologi Penelitian Hukum, Jakarta. PT. Raja Grafindo Persada.

Sugiarto, Umar Said, 2013. Pengantar Hukum Indonesia. Jakarta. PT. Sinar Grafika.

Yani ahmad, Wijaya Gunawan, 2005. Jaminan Fidusia. Jakarta. PT. Raja Grafindo Persada.

B. PeraturanPerundang-Undangan

Indonesia, Kitab Undang-Undang Hukum Perdata, (KUHper).

Indonesia, Undang-Undang No. 42 Tahun 1999. Tentang Jaminan Fidusia.

Indonesia, Undang-Undang No.10 Tahun 1998. Tentang Perbankan.

Indonesia, Undang-Undang No. 4 Tahun 1996. Tentang Hak Tangungan.

C. Internet

http://www.Unsri.blogspot.com eksekusi objek jaminan fidusia. Tanggal 12-juli2017 pukul 13.15Wita

http://www.Irmadevita.com. pembahsan PP Eksekusi Jaminan Fidusi Berdasarkan Peraturan Kapolri No.8 Tahun 2011, Tanggal 12-Juli-2017 pukul 13.00wita.

http://www.sharethispost.com Eksekusi Fidusia, Hukum Jaminan, Jaminan Fidusia, Leasing, multifinence, Tanggal 12-juli-2017 Pukul.13.15Wita.

http://www.velina Frisca.com.Potensi Sumber DayaManusia Kabupaten Lombok Timur, Tanggal 20-Agustus-2017, Pukul. 02.00Wita.

http://www.wikipedia.com, Pengertian Sosiologi Tanggal-30-Agustus 2017. Pukul. 23.11Wita.

http://www.wodpres.com Sosiologi Hukum, Di akses Tanggal 30 Agustus 2017 Pukul. 23.48Wita

Wawancara

Kuswanto, Heri. Wawancara Dengan Rpc. FIFGROUP Cabang Selong Lombok Timur. Tanggal 15, Agustus 2017. Pukul 09.00

Rofii, Muhamad. Nara Sumber Debitur FIFGROUP Cab. Selong Lombok Timur. Wawancara Tanggal 13. Agustus. 2017 Pukul. 19.00Wita 